\title{
China in UN Peacekeeping Operations: A 30-Year Assessment (1990-2019)
}

\section{Renan Holanda Montenegro*}

\begin{abstract}
This article presents a broad assessment of Chinese personnel deployments to peacekeeping operations (PKOs) for the past three decades (1990-2019). To this end, an original dataset was built with data collected from the UN Department of Peace Operations. The following four indicators were considered in the analysis: (i) total personnel contribution per year; (ii) personnel contribution per mission; (iii) personnel contribution in relation to the mission's total contingent; and (iv) personnel in a given mission in relation to the total personnel dispatched by China that year. Generally speaking, UN missions in Liberia (UNMIL) and South Sudan (UNMISS) have been the main destinations of Chinese peacekeepers in the 21st Century, while Cambodia (UNTAC) was by far the only place where China got deeply involved during the 1990s. In addition to displaying descriptive data, the paper also briefly analyses Chinese engagement in these operations.
\end{abstract}

Keywords: China; peacekeeping operations; UNMIL; UNMISS; UNTAC.

\section{Introduction}

The People's Republic of China (PRC) officially joined the United Nations (UN) in 1971. Almost two decades later, in 1989, the country made its first personnel contribution to peacekeeping operations (PKOs): 20 civilian observers were sent to Namibia to assist the United Nations Transition Assistance Group (UNTAG) in its exercise of monitoring elections (Gill and Huang 2009; Zürcher 2019). In March 2004, China surpassed the United Kingdom and became the largest troop contributor among the five permanent members of the Security Council (UNSC), a position that it holds to this day. Since then, the country increased its contribution markedly, including not only observers and support teams (e.g. engineers and medical personnel), but also civilian police and even combat troops. In total, in 30 years of engagement in the peacekeeping regime, the PRC participated directly in 30 missions carried out in 21 different locations (countries, pairs of countries, or * Pernambuco Federal University (UFPE), Recife-PE, Brazil; renanholandamontenegro@gmail.com. ORCiD
0000-0002-4371-5466. 
regions), with a personnel contribution of almost 35000 officers (taking annual data for December 2019 as a reference). ${ }^{1}$

Several empirical efforts were advanced by researchers to unveil the main determinants of China's recent assertive stance toward PKOs, such as hypothesis-testing through multivariate models (Lin-Greenberg 2009; Lawson 2011; Zhou 2013), qualitative analysis through observant participation and interviews (Fung 2016), and case studies (Barber 2014). Even so, many studies favour a historical narrative approach. Moreover, the literature is still missing a broad assessment exclusively focused on Chinese personnel deployments $^{2}$. This article intends to fill this gap. In order to do so, an original dataset was built with data gathered at the UN Department of Peace Operations (DPO) website.

The dispatch of Chinese peacekeepers will be captured according to four indicators: (i) its overall evolution over time; (ii) the absolute amount dispatched for each mission-year; (iii) the relative amount of personnel in relation to the mission's total contingent; and (iv) the relative amount in each mission in relation to all Chinese personnel dispatched that year. Two main findings are worth mentioning in advance: Liberia and South Sudan have been the main destinations of Chinese peacekeepers in the 21st Century; during the 1990s, Cambodia was, by far, the only place where China got deeply involved in terms of PKOs.

The paper proceeds by first presenting a literature review, where it discusses the phases of Chinese engagement in PKOs, and also the main determinants pointed out by pundits. Then, the methodology regarding measurement strategy is explained. Next, descriptive results are displayed, followed by three short analyses of the missions carried out in the aforementioned countries, namely Liberia, South Sudan and Cambodia. The final section presents concluding remarks and suggestions on upcoming future research.

\section{Literature Review}

China's global military footprint, while growing, is still quite limited to its immediate proximity. The country's ability to project hard power worldwide is relatively restricted to cyber warfare, its space program, and intercontinental ballistic missiles (Shambaugh 2013). Only quite recently China opened its first military base abroad, in Djibouti (Blanchard 2017; Wuthnow 2020). In that sense, participation in peacekeeping operations is the most striking feature of China's contribution to international security (Shambaugh 2013). In the following lines, China's involvement in these operations will be addressed first through a brief historical narrative and then through a discussion of the explanatory factors identified by pundits.

\section{Historical Phases}

As mentioned above, China's trajectory as a contributor to UN PKOs started in 1989. In the aftermath of its accession to the United Nations, China basically maintained its pre1971 stance regarding these missions - one of 'strong opposition' and 'acrimony toward 
the UN', in which the organisation was portrayed 'as an instrument for the US and USSR to expand their respective Cold War spheres of influence' (International Crisis Group 2009: 3). Indeed, the first decade of Chinese membership in the UNSC is described as a period of 'opposition and non-participation' (International Crisis Group 2009: 4) or a time of 'inactive policy' (He 2007: 16). Up to 1980, China condemned both the creation and continuation of all UN PKOs, refused to contribute financially and through personnel, and did not vote on resolutions related to the issue.

From 1981 on, China began to change its attitude, voting for the first time in support of a UNSC resolution (Pang 2005). A year later the country also began to contribute financially, by paying its peacekeeping dues. Besides that, while abstentions remained China's standard vote, Beijing started to provide explanations for its behaviour. Then, the third phase of this narrative was characterised by the rising profile of China's engagement, clearly observed in the first contributions of observers to Namibia (1989) and to the Middle East (1990). ${ }^{3}$ The first time China sent a military unit to a PKO was in 1992, namely to the UN Transitional Authority in Cambodia (UNTAC). As Graph 1 will further show, this year is a clear outlier in China's initial contribution trajectory.

A fourth phase came to the fore in the late 1990s, when China became more flexible with its historical policy of non-intervention and started to support peace enforcement missions. Since 2013, China enhanced its contribution profile and started to deploy combat troops, encompassing what is viewed as a fifth and current phase (Fung 2016). This new proactive and more conflict-engaged profile started in Mali and recently reached its pinnacle with the deployment of China's first complete infantry battalion to South Sudan (China Daily 2014).

\section{Determinants}

Many determinants can explain the Chinese decision to deploy personnel to a given mission. A useful departing point is to recognise that China's engagement in PKOs partially derives from its domestic process of opening reforms initiated in late 1970s. Without the huge economic development that 'provided the country with resources, confidence, and enthusiasm to fulfil its global peace engagement strategy' (Lei 2011: 344), it would not be possible to see a proactive China in the peacekeeping regime nowadays.

This relationship between economic growth and a more active role in safeguarding world peace is at the heart of the notion of responsible power (Chan 2013; Sieckmann and Triebel 2018). The term was first coined by Premier Zhu Rongji, meaning that 'China was not only a responsible economic player but also a political one in upholding justice and peace' (Pang 2005: 96-97). In fact, saying that a country is a responsible power can mean many things, but two stances at least must be fulfilled: firstly, it must play an active international role by providing resources to stability, prosperity, and development; and secondly, it must take international obligations seriously (Xia 2001).

A quite different theoretical claim points out that China's deployments are not merely a result of its economic growth, but a way of protecting the country's overseas interest 
instead. This kind of mercantilist argument is particularly well seen in Western press coverage, which claims that China is associated 'with deal-making rather than peacekeeping' (Allen 2015) in Africa and that massive deployment to South Sudan has the purpose of 'ensure the safety of its workers and assets' and 'guarantee a steady flow of energy for domestic consumption' (Bariyo 2014). With regard to investments, a recent correlation analysis concluded that 'investment levels do not necessarily lead to increased personnel counts', despite the fact that Chinese peacekeepers are more likely to be present in countries that also host significant Chinese investment (Best 2020).

Another factor that explains Chinese presence in peacekeeping operations is the determination to isolate Taiwan diplomatically, although the available evidence does not point to strictly 'quid pro quo' behaviour (i.e. the sending of personnel contingent on changing diplomatic recognition). Haiti, for example, is one of the countries which has historically received the highest number of Chinese peacekeepers on average, and the Caribbean state maintains diplomatic ties with Taiwan. On the other hand, China exercised its veto power in the past concerning the missions in Guatemala (1997) and Macedonia (1999) (Lanteigne and Hirono 2012). Recently, China also used its diplomatic bargaining power to get Liberia to drop recognition to Taiwan in order to receive a stabilisation force from the UN (Medeiros 2009).

In addition to safeguarding economic and diplomatic interests, analysts also note that participating in UN PKOs is a way to improve the modernisation process of China's People's Liberation Army (PLA). The country's new approach to security issues indicates that PLA's orientation is no longer confined to internal security (Mulvenon 2009). Therefore, Beijing's commitment to the peacekeeping regime provides the army with relevant onthe-ground experience abroad, as well as increases experience in military-to-military diplomacy, and improves its capabilities in MOOTW (military operations other-than-war) situations (Gill and Huang 2009; Li 2011; Lanteigne 2018).

Finally, it can also be argued that China's recent deeper involvement in UN PKOs is due to its socialisation in the peacekeeping regime, resulting in greater compliance with multilateral norms. Two complementary processes must be mentioned. The first is Beijing's initial experience in peacekeeping during the 1990s, that made the country able to reinterpret its understanding of the peacekeeping regime, particularly with regard to the use of force. The second concerns the reforms conducted in UN PKOs after the Brahimi Report was published in the year 2000. One of the recommendations brought up by the Report, which is also an old claim of China, was the restriction of the use of force to safeguard missions. Analysis of China's voting behaviour on the Security Council reveals that Beijing offers broad diplomatic support to the new structure of operations implemented with the adoption of the Brahimi Report (Stähle 2008). ${ }^{4}$

Despite the large number of determinants raised by the literature to explain China's deeper involvement in PKOs, there is some consensus around the non-existence of a great rationale behind China's personnel contribution, in such a way that the country's decision-making process is probably guided by a case-by-case logic. 


\section{Methodology}

To present a general assessment regarding China's involvement in UN PKOs, a dataset was built encompassing all personnel deployments made by the country since the beginning of its trajectory as a peacekeeping state. The analysed period runs from 1990 to 2019, covering 30 years of Chinese participation in the peacekeeping regime. Inputs in the dataset were recorded regarding troop levels on December 31 of each year, except in the years of 1990 and 1998, years in which the data is only available until November, and 1995 and 1997, due to a wide variation between the months of January and December. ${ }^{5}$

That said, Chinese personnel contribution was measured in four different ways: (i) contribution per mission, including those in which there is no participation; (ii) total contribution per year; (iii) contribution in relation to the total mission contingent; and (iv) contribution to a given mission in relation to the total personnel sent by China for all missions that year. Table 1 displays the labels of the indicators and their measures. All data were collected from the UN Department of Peace Operations (DPO) website (peacekeeping.un.org/en/troop-and-police-contributors). In order to capture real variance, I chose not to use dichotomous measurement (i.e. deployment or no deployment).

Table 1 - Four indicators of Chinese deployments to UN PKOs

\begin{tabular}{ll}
\hline Variable & Measurement \\
\hline Ctb_num & Personnel contribution per mission-year (discrete) \\
\hline Tot_CHN & $\sum$ Ctb_num per year (discrete) \\
\hline Ctb_perc_mission & $\begin{array}{l}\% \text { of Chinese contribution in a given mission-year related to the total contingent of the } \\
\text { mission (continuous) }\end{array}$ \\
\hline Ctb_perc_CHN & $\%$ of Chinese contribution in a given mission-year related to Tot_CHN (continuous) \\
\hline
\end{tabular}

Source: Table elaborated by the author.

The approach hereby proposed to analyse these indicators is mainly descriptive. Even so, the empirical investigation can provide an invaluable cartography of Chinese engagement in PKOs. At least four broader questions can be answered through our indicators:

- How has Chinese participation in PKOs evolved over the last thirty years (Tot_CHN)?

- In absolute terms, to which countries has China dispatched most of its peacekeepers (Ctb_num)?

- Relatively, which missions received the greatest percentage of Chinese peacekeepers in relation to the total contingent of UN peacekeeping personnel (Ctb_perc_mission)?

- Relatively, which missions have received the biggest share of Chinese deployments $\left(C t b \_p e r c \_C H N\right)$ ?

In the next section, descriptive statistics of all indicators will be shown first, displaying an overview of these four variables. Particular attention is given to the evolution of deployments over time and the countries that historically have received the largest part of Chinese peacekeepers. In order to do so, the investigation proceeds by unveiling the dynamics revealed by Tot_CHN. Next, the other indicators are dissected through a closer 
look at maximum values in our dataset. Finally, short case studies regarding relevant destinations of Chinese peacekeepers are brought to the discussion.

\section{Findings}

Altogether, our dataset has 520 observations. Between 1990 and 2019, China's average total annual personnel contribution to PKOs (Tot_CHN) was 1300. The average annual contribution per mission (Ctb_num) was 67. On average, Chinese personnel comprised about $1.3 \%$ of all missions (Ctb_perc_mission) during the analysed period. The $5.76 \%$ average for Ctb_perc_CHN also indicates that the Chinese contribution is relatively well distributed among the various missions in which the country takes part, although this scenario is changing recently, as will be discussed in the following paragraphs. A summary of all four indicators can be seen in the table below.

Table 2 - Descriptive statistics

\begin{tabular}{llllll}
\hline & N & Minimum & Maximum & Mean & SD \\
\hline Tot_CHN & 520 & 5 & 3045 & 1300.47 & 1066.78 \\
\hline Ctb_num & 520 & 0 & 1080 & 67.12 & 169.28 \\
\hline Ctb_perc_mission & 520 & .00 & 19.35 & 1.34 & 2.50 \\
\hline Ctb_perc_CHN & 520 & .00 & 100.00 & 5.76 & 12.29 \\
\hline \multicolumn{5}{r}{ Source: Table elaborated by the author, based on data available in UN Peacekeeping (2020) }
\end{tabular}

By analysing the annual evolution of Chinese deployments over time (Tot_CHN), Graph 1 clearly shows a huge growth of the country's participation in UN PKOs from the 21st century onwards. As mentioned earlier, 1992 is an outlier during the early stages of Chinese engagement, when a personnel contribution of 488 (Tot_CHN) was recorded, with Cambodia being responsible for $92 \%$ of that total (Ctb_perc_CHN) - 448 troops. This deviation in the early stages of Chinese involvement in the peacekeeping regime is represented by a small 'triangle' located on the left bottom of Graph 1.

According to the literature, the fourth historical phase of China's participation in PKOs initiated, in fact, in 1999, as the country supported peace enforcement missions for the first time. Nevertheless, up to 2003, Chinese personnel deployment was restricted to a few hundred. In 2004, personnel contributions grew by almost 190\%, from 358 to 1036, mainly due to the Chinese involvement in Liberia (UNMIL). That same year, China's participation increased from 7 to 12 operations (of a total of 17). Another considerable inflection occurred from 2014 to 2015, when the contribution jumped from 2181 to 3045 (roughly a $40 \%$ increase) - this time, the infantry battalion dispatched to South Sudan (UNMISS) was the main reason behind these figures. In 2015, the peak year of the series (the maximum value of Tot_CHN in Table 2), China contributed to 10 of the 18 ongoing operations. In the general country profiling, it ranked 9th in terms of personnel contribution that year, alongside Bangladesh $\left(1^{\text {st }}\right)$, Ethiopia $\left(2^{\text {nd }}\right)$, India $\left(3^{\text {rd }}\right)$, Pakistan $\left(4^{\text {th }}\right)$, Rwanda $\left(5^{\text {th }}\right)$, Nepal $\left(6^{\text {th }}\right)$, Senegal $\left(7^{\text {th }}\right)$, and Ghana $\left(8^{\text {th }}\right)$. 


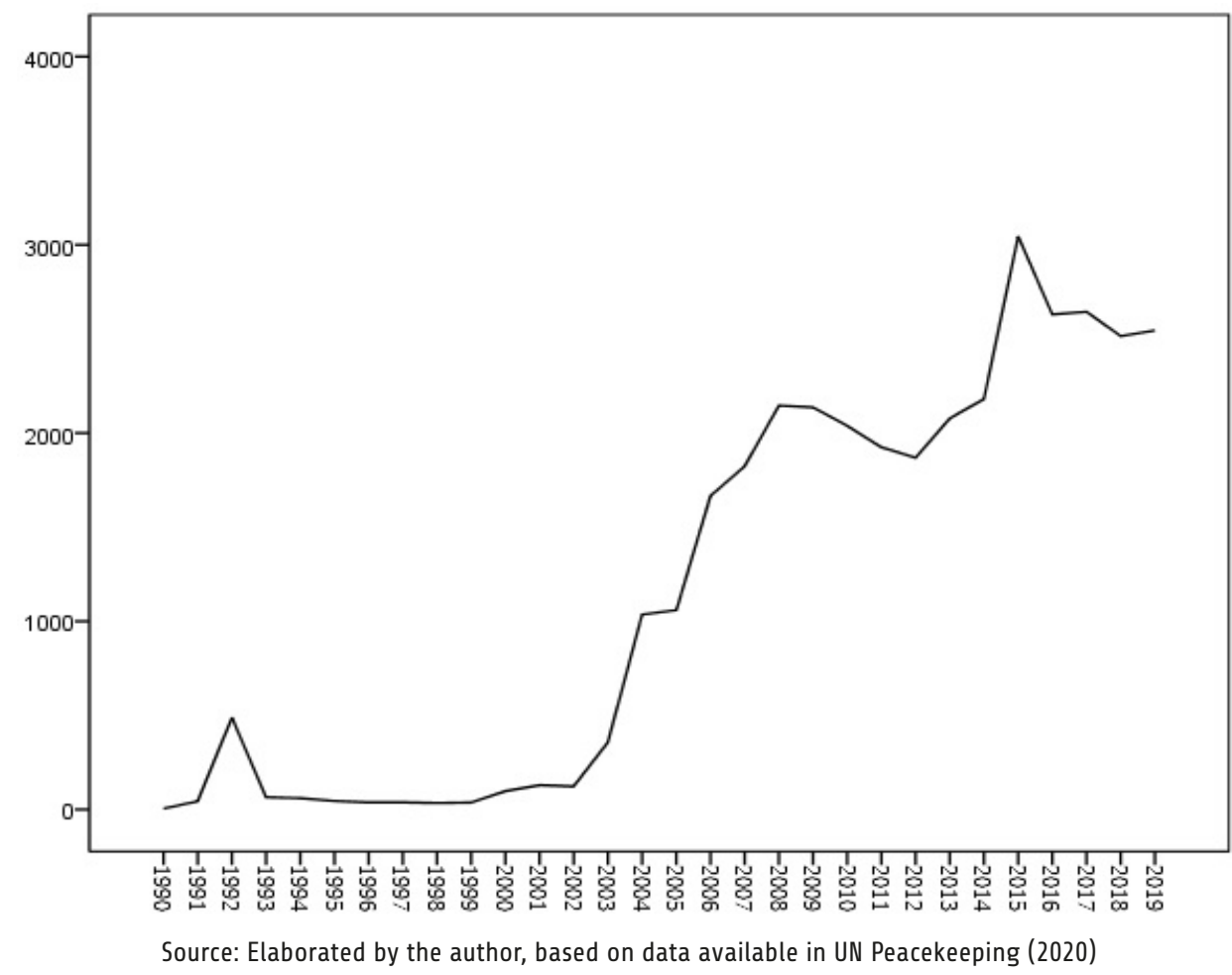

On average, seven countries have historically concentrated most of the Chinese personnel deployed to peacekeeping operations (Ctb_num), namely South Sudan (mean of Chinese personnel contribution: 754; observations: 9), Liberia (mean=396; $n=20$ ), Mali $($ mean $=369 ; n=7)$, Cambodia (mean $=225 ; n=2)$, Sudan ( $m e a n=216 ; n=28)$, the Democratic Republic of the Congo (mean=188; $n=21$ ), and Lebanon (mean=163; $n=30$ ). Haiti $($ mean $=39 ; n=22)$, East Timor ( $m e a n=25 ; n=13)$, and Western Sahara (mean=14; $n=29$ ) complete the top ten list. Nevertheless, as the contribution to Cambodia is a deviant observation in the dataset, it follows that the most part of Chinese personnel was received by six countries, five of which are located in Africa.

Within a period of 30 years, the African continent received about $70 \%$ of all personnel sent by China for peacekeeping operations. It is quite true, however, that this is due to the massive recent engagement in South Sudan, the first country to receive a complete infantry battalion sent by the PLA and home to more than $40 \%$ of all Chinese deployments since 2016. Just to compare, the average personnel contribution to Africa provided by all UN members (including China) was around $46 \%$ in the same interval. In fact, the distribution of the Ctb_num variable by continent shows that the average for Africa (138.26) is far ahead of Asia (31.45), America (24.6), and Europe (1.45). 
While the means displayed in Table 2 end up hiding a recent trend of a large increase in Chinese contribution, the maximum values point to interesting clues. In that sense, Table 3 below shows the ten higher records in the dataset for each indicator.

Table 3 - Top 10 Maximum Values

\begin{tabular}{|c|c|c|c|c|}
\hline & Tot_CHN & Ctb_num & Ctb_perc_mission & Ctb_perc_CHN \\
\hline $1^{\text {st }}$ & $\begin{array}{l}3045 \\
(2015)\end{array}$ & $\begin{array}{l}1080 \\
\text { (UNMISS, 2019) }\end{array}$ & $\begin{array}{l}19.35 \% \\
\text { (UNMIL, 2017) }\end{array}$ & $\begin{array}{l}100 \% \\
\text { (UNTSO, 1990) }\end{array}$ \\
\hline $2^{\text {nd }}$ & $\begin{array}{l}2644 \\
(2017)\end{array}$ & $\begin{array}{l}1068 \\
\text { (UNMISS, 2015) }\end{array}$ & $\begin{array}{l}16.67 \% \\
\text { (UNAMA, 2017) }\end{array}$ & $\begin{array}{l}91.8 \% \\
\text { (UNTAC, 1992) }\end{array}$ \\
\hline $3^{\text {rd }}$ & $\begin{array}{l}2630 \\
(2016)\end{array}$ & $\begin{array}{l}1067 \\
\text { (UNMISS, 2018) }\end{array}$ & $\begin{array}{l}15.83 \% \\
\text { (UNMIL, 2016) }\end{array}$ & $\begin{array}{l}64.25 \% \\
\text { (MONUC, 2003) }\end{array}$ \\
\hline $4^{\text {th }}$ & $\begin{array}{l}2545 \\
\text { (2019) }\end{array}$ & $\begin{array}{l}1061 \\
\text { (UNMISS, 2017) }\end{array}$ & $\begin{array}{l}14.13 \% \\
\text { (UNMIL, 2015) }\end{array}$ & $\begin{array}{l}57.63 \% \\
\text { (UNMIL, 2004) }\end{array}$ \\
\hline $5^{\text {th }}$ & $\begin{array}{l}2515 \\
\text { (2018) }\end{array}$ & $\begin{array}{l}1055 \\
\text { (UNMISS, 2016) }\end{array}$ & $\begin{array}{l}12.35 \% \\
\text { (UNMIL, 2014) }\end{array}$ & $\begin{array}{l}56.19 \% \\
\text { (UNMIL, 2005) }\end{array}$ \\
\hline $6^{\text {th }}$ & $\begin{array}{l}2181 \\
(2014)\end{array}$ & $\begin{array}{l}729 \\
\text { (UNMIL, 2013) }\end{array}$ & $\begin{array}{l}11.9 \% \\
\text { (UNOMIL, 1994) }\end{array}$ & $\begin{array}{l}56.12 \% \\
\text { (UNTAET, 2000) }\end{array}$ \\
\hline $7^{\text {th }}$ & $\begin{array}{l}2146 \\
(2008)\end{array}$ & $\begin{array}{l}721 \\
\text { (UNMIL, 2014) }\end{array}$ & $\begin{array}{l}9.76 \% \\
\text { (UNMLL, 2013) }\end{array}$ & $\begin{array}{l}56.10 \% \\
\text { (UNMISET, 2002) }\end{array}$ \\
\hline $8^{\text {th }}$ & $\begin{array}{l}2136 \\
(2009)\end{array}$ & $\begin{array}{l}667 \\
\text { (UNMIL, 2015) }\end{array}$ & $\begin{array}{l}9.72 \% \\
\text { (UNOTIL, 2005) }\end{array}$ & $\begin{array}{l}46.51 \% \\
\text { (UNTAET, 2001) }\end{array}$ \\
\hline $9^{\text {th }}$ & $\begin{array}{l}2078 \\
(2013)\end{array}$ & $\begin{array}{l}597 \\
\text { (UNMIL, 2004) }\end{array}$ & $\begin{array}{l}8.37 \% \\
\text { (MINURSo, 2004) }\end{array}$ & $\begin{array}{l}45.71 \% \\
\text { (MINURSO, 1998) }\end{array}$ \\
\hline $10^{\text {th }}$ & $\begin{array}{l}2039 \\
(2010)\end{array}$ & $\begin{array}{l}595 \\
\text { (UNMIL, 2005) }\end{array}$ & $\begin{array}{l}8.37 \% \\
\text { (MINURSO, 2005) }\end{array}$ & $\begin{array}{l}45.45 \% \\
\text { (MINURSO, 1991) }\end{array}$ \\
\hline
\end{tabular}

Source: Table elaborated by the author, based on data available in UN Peacekeeping (2020)

As mentioned above, the largest personnel contribution within a year (3045 peacekeepers) occurred in 2015 alone. China surpassed the mark of a thousand people sent per year in 2004 (Tot_CHN=1036), having exceeded two thousand for the first time in 2008 (Tot_CHN = 2146), reaching the level of three thousand only once. As such, ceteris paribus, the general mean of deployments - 1300 between 1990 and 2019 - is expected to increase over the course of this century. The low average contribution per mission (Ctb_num =67) also masks recent figures because of the high number of observations in the dataset in which there was zero (289) or small personnel deployments, that is, observations in which contributions were below 50 and above zero (141). Still with regard to Ctb_num, the maximum value of 1080 was observed in South Sudan in 2019. In the time span here analysed, this African country was the only one to receive contributions above a thousand. These contributions occurred every year between 2015 and 2019.

Liberia has also been a relevant destination for Chinese personnel. Taking into account Ctb_num figures, this country was the main destination of Chinese troops for a decade, between 2004 and 2014. During this interval, the minimum amount of personnel deployed was 569 in 2008, while the maximum was 729, in 2013. Summing up, the 17 highest observations for Ctb_num were recorded in South Sudan (5) and Liberia (12). Sudan occupies the last three positions in this top 20 ranking. There were 469 Chinese peacekeepers registered in December 2006, 474 in 2008 and 478 in 2010. In 2015, of the 
total 3045 peacekeepers dispatched by China to serve in peacekeeping operations, 1068 were at UNMISS and 667 at UNMIL, accounting for 57\% of all peacekeeping personnel deployed that year.

Moreover, all observations above 10\% for Ctb_perc_mission were recorded for Liberia between 2014 and 2017 - except for UNAMA in 2017, in Afghanistan, which is a deviant case given that the mission's contingent encompassed only six peacekeepers. From 2013 to 2017, China's contributions corresponded, respectively, to $9.76 \%, 12.35 \%, 14.13 \%, 15.83 \%$ and $19.35 \%$ of the contingent assigned to UNMIL. In 2015 and 2016, China also contributed just over $8 \%$ of the total UNMISS contingent. In 2017, the share percentage was $7.3 \%$. The greatest observations for Ctb_perc_CHN also indicate some concentration of Chinese participation in Africa. Despite that, the maximum value of $100 \%$ reported for this indicator refers to 1990, when China only participated in UNTSO. Therefore, it informs very little. The second maximum observation was recorded for UNTAC.

Indeed, an assessment of the Chinese trajectory in the 1990s clearly demonstrates the relevance given to the mission in Cambodia. As said, the PRC dispatched 448 troops to its war-torn, crisis-immersed neighbouring country - a record of $91.8 \%$ in the Ctb_perc_ CHN indicator. With the exception of UNTSO and UNTAC, the UN mission in Western Sahara (MINURSO) received the largest proportion of China's peace effort during the 1990s (around 45\% in 1991, 1995 and 1998). Yet, overall participation numbers were very small: no more than 20 Chinese peacekeepers were sent to this Moroccan region each year.

During the years of 2000 and 2001, China allocated a large part of its deployments (56\% and 46.5\%, respectively) to the United Nations Transitional Administration in East Timor (UNTAET). In the year 2000, there were 55 Chinese peacekeepers; in 2001, 60. In 2002, China deployed $56 \%$ of its personnel to the same country (69 peacekeepers) once again. In 2003, the DR Congo (MONUC) received 230 Chinese peacekeepers. This number was equivalent to $64 \%$ of all personnel deployed by the country that year. In the years of 2004 and 2005, Liberia concentrated the detachments: respectively, $57.6 \%$ and $56 \%$ of the Chinese blue helmets went to UNMIL.

The descriptive assessment provided by the analyses above clearly demonstrates that Cambodia was, by far, the only place where China got actively involved during its early experience as a peacekeeping state. In the 21st century, Liberia and South Sudan have been the main destinations of Chinese peacekeepers. Therefore, it may be reasonable to conclude that briefly investigating the broader reasons behind these findings is a worthwhile effort.

\section{United Nations Transitional Authority in Cambodia (UNTAC)}

At large, a complete understanding of Chinese involvement in UNTAC can be traced back to Cold War geopolitical dynamics. An interesting departing point is the Vietnam War. Cambodia's official stance was one of neutrality, but its leader Norodom Sihanouk - the hero at the time of the country's independence in 1953 - ceded the country's North-eastern part to Ho Chi Minh forces to operate against the United States (US)-South Viet- 
namese coalition. In March 1970, after nearly a year of several attacks against communist 'sanctuaries' in Cambodia, a military coup led by Prime Minister General Lon Nol and Prince Sisowath Sirik Matak replaced the monarchy of King Sihanouk with a pro-American republican regime.

The US-Saigon coalition stepped up attacks, the US invaded Cambodia in April 1970, and shortly thereafter a civil war broke out between Lon Nol's forces and the Khmer Rouge (KR), the latter winning in 1975. In a figurative gesture, Sihanouk was appointed head of state but resigned after a year due to disagreements with Pol Pot, leader of the new government. It was the outbreak of another political standoff in Cambodia. During the Vietnamese conflict, the Khmer Rouge and North Vietnam were occasional allies, but each directed allegations against the other shortly after the fall of Saigon, in April 1975.

In December 1978, Vietnam invaded Cambodia, which had been named 'Democratic Kampuchea' in 1976. At that time, the PRC was Pol Pot's main international ally, while Hanoi - Soviet Union's ally - was sceptical about 'Mao's 'Cultural Revolutionary' policies abroad and about Beijing's rapprochement with the United States in the early 1970s' (Aksu 2003: 180). In that context, China's stance towards Cambodia was one of close relations with both rival factions: 'To the Khmer Rouge, China sent political, economic and military support (...) from the early 1970s to the end of the 1980s,' while it 'twice allowed Sihanouk to form a government in exile in Beijing, and once to seek refuge there' (Hirono 2011: 332). In short, Beijing backed two opposing Cambodian governments from April 1976 to December 1978.

On the other hand, Sino-Vietnamese relations were very troublesome, ranging from border disputes to the expulsion of ethnic Chinese in Vietnam. In January 1979, the Vietnamese invasion of Cambodia succeeded, and the Khmer Rouge was ousted, replaced by a communist pro-Hanoi government. The Democratic Kampuchea became the People's Republic of Kampuchea (PRK). Afraid of being encircled, China invaded Vietnam a month later (Christensen 2006). Both sides claimed victory, but the fact is that Beijing did not accomplish its main objective: to deter or even delay the establishment of a pro-Vietnamese regime in Phnom Penh.

The Khmer Rouge sought shelter along the Thai-Cambodian border and formed a coalition with two less powerful anti-government guerrilla factions: 'The royalist FUNCINPEC $^{6}$, founded by Sihanouk; and the republican Khmer People's National Liberation Front (KPNLF), led by Lon Nol's former Prime Minister Son Sann' (Findlay 1995: 1). This threepart alliance established the so-called Coalition Government of Democratic Kampuchea (CGDK), keeping the Cambodian seat at the UN.

On the ground, the situation reached a stalemate, as the two most powerful factions, the PRK and the KR, could not defeat each other. Hence, a window of opportunity for all sides to engage in a diplomatic alternative emerged. In addition, global and regional contexts played in their favour. Sino-Vietnamese relations improved after Vietnam withdrew its troops from Cambodia in 1989; the Soviet Union stopped sending aid; and ASEAN's booming economies sponsored an informal campaign to turn Indochina from a battlefield into a profitable marketplace. 
On 16 October 1991, the Security Council (UNSC) approved Resolution 717, establishing the United Nations Advance Mission in Cambodia (UNAMIC). The mission was designed 'to assist the four Cambodian parties to maintain their ceasefire during the period prior to the establishment and deployment of the UNTAC and to initiate mine-awareness training of civilian populations' (UNAMIC n.d.). On October 23, a Comprehensive Political Settlement mostly known as the 'Paris Agreements' was signed, being fully supported by the Security Council on October 31. Put simply, these accords were 'designed to end a conflict that had been fuelled by bitter Cold War enmities between the major powers, who supplied arms and money to the different Cambodian factions' (Ponniah 2018). Beyond the four Cambodian warring parties, 18 other states attended the peace conferences, including China, which also sent personnel to the peace mission. On 9 November 1991, UNAMIC became operational.

Through Resolution 745 of 28 February 1992, the UNSC established UNTAC for a maximum period of 18 months. The initial deployment phase began on 15 March 1992 (UNTAC n.d.). In April 1992, China 'dispatched an engineer unit of 400 troops to UNTAC', 'the first formed military unit committed by China to the UNPKOs' (State Council, 2020). As seen above, the UN mission in Cambodia was the only such Chinese engagement during the 1990s. Indeed, 'the Chinese engineering contribution to UNTAC was invaluable to the overall operation, given that they contributed approximately 19 per cent of UNTACs entire engineering troop complement' (Hirono 2011: 334).

It is beyond the scope of this article to undertake a detailed analysis of the mission or the elections held in Cambodia. Rather, the goal is to provide an overview of the general background regarding Chinese engagement. To sum up, this notable deployment happened due to a number of situation-specific factors, such as Cold War dynamics, 'geographical proximity, initial involvement with the authorisation process in the Security Council, and host-nation consent' (Kim 2006: 297). It is also worth mentioning that, at that point, following the Tiananmen episode in 1989, China was willing to portray itself as a responsible power, member of the international community, 'ready to develop coordination and cooperation with other countries in the field of non-traditional security issues and encourage ARF (ASEAN Regional Forum) to have further non-traditional security dialogue and cooperation' (Ministry of Foreign Affairs 2002). China's contribution indexes to UNTAC were overcome only in the early 2000s, following its even greater commitment to a UN-sponsored mission in Liberia.

\section{United Nations Mission in Liberia (UNMIL)}

While the Cold War played a fundamental explanatory role in understanding Chinese involvement in UNTAC, there is no doubt that the 'Taiwan factor' is among the main determinants behind the PRC's decision to dispatch an engineer unit of 275 troops, a transport unit of 240 troops and a medical unit of 43 troops to UNMIL in December 2003 (State Council 2020). As a matter of fact, the effort to isolate Taiwan is a consistent driver of PRC's activities at the Security Council since its official membership in 1971. 
Nevertheless, despite vetoing UN assistance to states with diplomatic ties to Taiwan at least for three times, 'China's recent anti-Taiwan diplomacy in the UN reflects a greater sophistication and less-confrontational approach,' operationalising PKOs as instruments to reduce Taiwan's international space 'without using the veto option (or even threatening to veto)' (Medeiros 2009: 185).

Sino-African ties are also relevant to understanding China's great involvement in UNMIL. Shortly after the 1949 revolution, the PRC put in place a foreign policy strategy of rapprochement with African countries, especially through a rhetoric of anti-colonial and anti-imperialist solidarity, expressed at the Bandung Conference (1955). In the early 1960s, Premier Zhou Enlai held his famous 'safari' on the continent, visiting ten countries. At that point, China was already demonstrating that it would have an independently oriented diplomacy, not aligned with either of the two great poles of the Cold War. In the 1970s, China provided a large volume of foreign aid through partnerships and infrastructure investments that represented not only constructions, but rather 'national symbols of independence' (Li 2007: 71), such as the Tanzania-Zambia Railway (TAZARA). As a result of this diplomatic campaign, more than 20 African states established formal ties with the PRC in the 1970s, including Liberia.

In fact, Sino-Liberian bilateral ties are marked by many turnarounds. It was on February 1977 that China and the Republic of Liberia established diplomatic relations. However, Liberia stepped back on October 1989, during the Samuel Doe regime, and resumed diplomatic relations with Taiwan. 'Doe and his newly formed National Democratic Party of Liberia (NDPL) emerged victorious from the 1985 elections after eliminating major opponents from contention and flagrantly rigging the count' (Harris 1999: 433). On August 1993, Beijing and Monrovia restored its formal ties. Then, on September 1997, the Charles Taylor regime announced its recognition of 'two Chinas', a decision followed by a quick response from Beijing, which suspended diplomatic relations with Liberia.

It is relevant to mention that Liberia faced a brutal civil war between 1989 and 1997 that 'claimed the lives of almost 150,000 people - mostly civilians - and led to a complete breakdown of law and order' (UNMIL n.d.). In 1993, the Security Council approved the United Nations Observer Mission in Liberia (UNOMIL), designed to support the peace efforts led by the Economic Community of West African States (ECOWAS), which brokered a peace agreement in Cotonou, Benin.

Presidential elections were originally scheduled for 1994, but the upsurge of conflicts between rival factions made it impossible to carry them out. After a number of supplementary peace talks amending the Cotonou agreement, and with a ceasefire in force, the UN successfully observed the conduct of the elections in July 1997. Charles Taylor, former ally of Samuel Doe who was sent to a US prison for the charge of embezzling money, became president. But the defeated candidate, Ellen Johnson-Sirleaf, did not consider the elections fair. She stated that soldiers from the ECOWAS observer force 'had voted or told people how to vote' (Harris 1999: 439).

Additionally, the Independent Electoral Commission (IECOM), established in January 1997, received a donation of US $\$ 1 \mathrm{~m}$ from the Taiwan government, well-known 
as Taylor's international ally, an episode regarded by some as indicative of bias. Indeed, Taylor's decision to recognise 'two Chinas' was made just after his election. UNOMIL's mandate ended on September 1997, and in November the UN established the United Nations Peace-building Support Office in Liberia (UNOL), tasked primarily with assisting the Government in consolidating peace following the elections. Notwithstanding these efforts, hostilities between the government and opposition groups witnessed an escalation, leading to the resumption of civil war in Liberia. After years of intense conflict, Charles Taylor resigned on 11 August 2003.

A month later, the UN Secretary-General submitted a report (S/2003/875) recommending a peacekeeping operation in Liberia. At least a six-month period was necessary for the initial mobilisation and deployment of the peacekeeping force, but China only supported a three-month mandate. Chinese diplomats are known to have acted behind the scenes to secure UN support for Beijing's diplomatic recognition by the post-Taylor government. 'A month after the September 2003 UNSC resolution (1509) authorising the stabilisation force in Liberia for 12 months, the country and China re-established diplomatic relations (on October 11, 2003)' (Medeiros 2009: 185). The Chinese Embassy in the Liberian capital reopened on January 12, 2004. 'In August 2005, the Liberia National Transitional Legislative Assembly passed into law a resolution upholding One-China Policy which was reiterated by the $52^{\text {nd }}$ legislature in October 2006' (Embassy of the PRC in Liberia n.d.). In short, contemporary Sino-Liberian diplomatic relations were established during a Transitional Government in Monrovia.

This diplomatic battleground between Beijing and Taipei had its raison dêtre. Charles Taylor visited Taiwan on at least three occasions during his presidency and received more than US\$20m from the Taiwanese government, used to 'cover military salaries, Balkan arms deals and the airlift of wounded bombing victims,' according to Taylor's own words in court. A Taiwanese diplomat said that Taylor exerted 'tremendous pressure' in order to get these funds and 'threatened to cut off relations' (Carvajal 2010).

Therefore, it can be concluded that the quantitative leap in Chinese engagement in the peacekeeping regime at the beginning of the 21st century, influenced by UNMIL figures, was triggered to a large extent by the determination to isolate Taiwan internationally. As shown in Table 3, Chinese personnel contribution to UNMIL in 2004 and 2005 was close to 600 . After that, it took another decade to the international community to witness an even greater increase in China's engagement in PKOs.

\section{United Nations Mission in South Sudan (UNMISS)}

Although formal diplomatic relations were established in 1959, that is, three years after Sudanese independence, the history of the People's Republic of China's involvement in Sudan - and, since its independence in 2011, also in South Sudan - is much more recent. Basically, this bilateral axis was strengthened as of the 1990s, influenced, among other factors, by the distance and even opposition from the United States, and mainly due to the Chinese demand for oil. Sudan and South Sudan are oil-rich countries, and the latter has 
the third largest reserve in sub-Saharan Africa after Angola and Nigeria. Until the mid1980s, Sudan's oil market was restricted to American-led exploration through Chevron.

One event, which took place during the second civil war in Sudan (1983-2005), was particularly decisive for the distancing of the United States and the subsequent engagement of China: an attack against Chevron's facilities in February 1984, which left three employees dead. After that episode, production was halted. Without being able to count on the oil revenues, the Sudanese economy gradually waned and popular protests took to the streets of the capital Khartoum. In 1985, while the government tried to guarantee Washington's confidence and investments, a coup détat was carried out: President Jaafar Nimeiri was deposed and Sadiq al-Mahdi, a pro-Islam leader, took over his place.

In 1986, a Sino-Sudanese Economic and Trade Joint Commission was established. Shortly thereafter, in 1989, another coup brought the National Islamic Front (NIF) to power. The new leadership demanded that the Americans restart operations in the exploitation fields, otherwise they would be expelled (Jakobson and Zha 2006). The year of 1990 witnessed an official visit by Sudanese leader Omar al-Bashir to China in November, during which time he met with President Jiang Zemin in Beijing. In June, Bashir had already been to Malaysia. This Asian tour had a twofold objective: building closer ties with China and seeking alternatives for the development of the national oil industry. In the early 1990s, Chevron sold its concessions in Sudan. Just after, 'the current confrontational US foreign policy (...), culminating with the imposition of economic sanctions, opened the door for the China National Petroleum Corporation (CNPC) and Malaysia's national oil company Petronas to take the lead role in Sudan's oil industry' (Patey 2014: 58).

The first official investment agreement signed by the Chinese took place in 1995, through CNPC, the largest national company in the sector, but still unknown in the international market at that time. In the following year, CNPC had already become the main investor in Sudanese oil fields, with $40 \%$ of the assets in a consortium (Greater Nile Petroleum Operation Company) formed by the Canadian company Arakis (25\%), Petronas (30\%), and the Sudanese state-owned Sudapet (5\%). Tensions between the government and southern rebels continued until 2005, when the Comprehensive Peace Agreement (CPA) was signed, ending the second civil war and paving the way for South Sudan's independence, consummated in 2011 - the same year in which UNSC approved UNMISS.

A government that sought to make feasible a social pact between the two largest ethnic groups in the country was formed in South Sudan. The Dinkas appointed Salva Kiir as president, while the Nuers chosen Riek Machar as vice president. By the end of 2013, however, accusations that Machar was planning a coup against Kiir led to the outbreak of a new civil war, now restricted only to South Sudan, which in April 2014 already registered more than 10,000 deaths and hundreds of thousands of refugees. Six years later, it has displaced more than four million people. The refugee crisis in South Sudan is the largest in Africa, and the third largest in the world, after Syria and Afghanistan (USA for UNHCR n.d.).

Since the approval of UNMISS, the Security Council has extended its mandate and expanded its force more than once. With each renewal, new prerogatives and respon- 
sibilities were included in the resolutions. The Chinese decision to send a full infantry battalion to South Sudan only came after the adoption of Resolution 2155 in May 2014. In this document, the UN expressed the need for the UNMISS mandate to be used to contain violence against foreign civilians in risky areas for the first time. The resolution text read: the United Nations 'condemns attacks on oil installations, petroleum companies and their employees and the continued fighting around these facilities, and urges all parties to ensure the security of economic infrastructure' (UN Digital Library 2014: 8).

In January 2015, China sent its first full infantry battalion to a UN mission, specifically to South Sudan. Since then, as already mentioned, South Sudan accounts for around $40 \%$ of all personnel deployed to UN PKOs by China. Before that, Chinese personnel contribution to UNMISS was 359 in 2013 and 2014. Furthermore, CNPC is so involved in the country that it has made several donations and helped build an UNMISS official site for the protection of civilians, receiving thousands of internal displaced people (Meng 2019).

It should be noted that China had already carried out workers rescue operations due to the intensification of conflicts in South Sudan on other occasions. Indeed, the PRC has been increasingly committed to protecting its citizens living abroad. Between the mid1990 s and the beginning of the 21st century, about one million Chinese landed in Africa (French 2014). Specifically, there are more than a hundred Chinese companies operating in Sudan and South Sudan. In addition to the oil sector, there is Chinese capital in sectors such as construction, hydroelectric, and other industries.

Therefore, this economic presence reinforces the need for China to play a more active role in ensuring the region's security. This does not mean, however, that China's participation in UNMISS has the sole purpose of protecting Chinese workers - although their presence is surely a relevant factor taken into account by decision-makers - or guaranteeing oil export flows. All in all, it can be said that economic drivers largely explain Beijing's active diplomatic presence in the South Sudanese mediation process.

\section{Conclusions}

This article sought to conduct a comprehensive assessment of the first 30 years of Chinese involvement in UN PKOs. An original data set with four indicators was built in order to achieve this objective. Before analysing the data, the paper briefly addressed some relevant aspects previously covered by the literature, such as the historical evolution of China's participation in peace missions and the main determinants of troops deployment. As shown, a myriad of factors is raised by pundits to explain deployment decisions, such as economic and diplomatic interests, engagement in multilateral security arrangements, the desire to improve PLA's operational capabilities or to portray itself as a responsible power, and so on. A detailed observation of the data presented reinforces the claim that there is no major rationale guiding Chinese decision-making in the peacekeeping regime.

While the Cold War geopolitics and diplomatic concerns related to Taiwan were, respectively, among the main determinants behind Chinese deep engagement in UNTAC and UNMIL, energy security issues and the internationalisation of state-owned oil com- 
panies are crucial to unravel China's massive deployments to UNMISS. Personnel fatality episodes clearly demonstrate the substantial Chinese involvement in these three operations. Between 1990 and 2019, 14 Chinese peacekeepers died on duty, nine of them (64\%) on the aforementioned missions - three at UNTAC (one on 21 January and two on 21 May 1993), three at UNMIL (in 2004, 2005 and 2014) and three at UNMISS (on 10 and 11 July 2016 and November 2019) (State Council 2020).

Obviously, it is imperative to note that the determinants used to explain these deployments are not exhaustive. Geopolitics and diplomatic considerations, as well as energy security concerns, are indeed relevant drivers, but they cannot account for the whole picture. For example, countries such as Angola, Georgia, and Iraq, whose exports consist mainly of natural resources, have never received Chinese peacekeepers. ${ }^{7}$ Thus, it is impossible to understand the PRC's evolution as a peacekeeping state without taking into account a broad set of factors, ranging from bilateral relations with the host country to domestic events in China and its global reverberations, such as the economic reforms started in late 1970s, the unprecedented growth figures experienced during the 21 st Century and the consequent increase in material capabilities.

As a result, the perception that China cannot follow its path towards great power status without assuming certain responsibilities has become increasingly 'embedded' in political elites. Traces of evidence on this point are the launch of the PLA's 'new historic missions' - which point to the need to defend China's expanding national interests and uphold world peace - and the transition from a low-profile foreign policy to a more assertive one (Yan 2014; Sharman 2015). Under the low-profile strategy, the PRC 'avoided international security responsibility', presenting 'to other states an image of a selfish and threatening rising state' (Yan 2014: 182)

It would not be wrong to assert that the will to be seen as a responsible power works as a permanent driver of China's engagement in PKOs. This commitment to an assertive role in international security affairs is quite clear in the official rhetoric. In 2000, President Jiang Zemin's stated at the UN Millennium Summit that 'the big countries have an important responsibility for the maintenance of world and regional peace', and that they hence 'should respect the small ones, the strong should support the weak, and the rich help the poor' (Jiang 2000). According to an official document on 'Peaceful Development,' 'as countries vary in national conditions and are in different stages of development, they should match responsibility with rights in accordance with their national strength' (State Council 2011).

For future research, multivariate models that can shed light on the broad determinants of Chinese deployments - if any - would be interesting, since few empirical studies so far have applied statistical tools to evaluate the explanatory impact of some selected variables (Lin-Greenberg 2009; Lawson 2011; Zhou 2013). For example, it may be interesting to assess whether countries punished by United States or UN sanctions are more likely to receive Chinese contributions to peacekeeping operations. ${ }^{8}$ Another interesting indicator may be the diplomatic affinity between China and the host country, as China's new foreign policy strategy (Striving for Achievement) emphasises mutual trust and the character of 
previous relations. Of course, case studies are always welcome, especially those which can provide insightful evidence to support or discard theoretical claims.

The research community would also benefit from works that seek to disaggregate the Chinese state to understand how foreign policy actors directly related to peacekeeping efforts (e.g. PLA, Ministry of Foreign Affairs, state oil companies) are immersed in a complex decision-making tangle, since 'the characterization of the government in Beijing as a unified and coordinated entity' (International Crisis Group 2009: 15) does not accurately describe contemporary Chinese foreign policy. Additionally, the future agenda can evolve through investigations from the perspective of International Relations theories (Liu 2009). The discussions brought up here raise interesting points for some classical debates, such as the relevance of identity, even if triggered by material aspects. It is also interesting to note and compare how great powers behave in multilateral security arrangements. China's active engagement in peacekeeping operations is clearly different from the United States' unilateralist perspective (and even Russia's perspective) on the issue of military intervention.

Finally, it is imperative that future research efforts be able to rely on well-structured empirical analyses. Besides quantitative methods, qualitative tools are equally welcomed, such as in-depth interviews, participant observation, content analysis, process-tracing, etc. Historical narratives that are merely descriptive, albeit important, have already fulfilled their function. Theory-building is still in process regarding Chinese participation in UN PKOs.

\section{Notes}

1 Data gathered for the period between 1990, the first year for which there are official statistics provided by the UN, and 2019. In order to save space, here only the missions' acronyms have been listed, as follows: UNTSO, UNTAET, UNTAC, UNOTIL, UNOMSIL, UNOMIL, UNOCI, UNMIT, UNMISS, UNMISET, UNMIS, UNMIL, UNMIK, UNMIBH, UNMEE, UNIOSIL, UNIKOM, UNIFIL, UNFICYP, UNAMSIL, UNAMID, UNAMIC, UNAMA, ONUMOZ, ONUB, MONUSCO, MONUC, MINUSTAH, MINUSMA, and MINURSO. The 21 locations are: Middle East, East Timor, Cambodia, Sierra Leone, Liberia, Ivory Coast, South Sudan, Sudan, Kosovo, Bosnia, Ethiopia/Eritrea, Iraq/Kuwait, Lebanon, Cyprus, Afghanistan, Mozambique, Burundi, DR Congo, Haiti, Mali, and Western Sahara.

2 A report authored by Zürcher (2019) is pioneer in this sense, but it has two major differences compared to the present paper: it only analyses absolute deployment numbers (per year); and the time span goes from 1990 to 2017.

3 Civilian personnel deployed to Namibia and military observers to the Middle East.

4 For details regarding the Brahimi Report and its contemporary challenges, see Williams and Bellamy (2007).

5 In 1995, the total number of UN peacekeepers (relevant indicator to calculate one of our indicators) begins with 60 thousand in January and falls to 30 thousand in December (mean=59.656). In this year, I did choose data for the month of October. The same happened in 1997, so I did pick data for the month of July.

6 French acronym for 'United National Front for an Independent, Neutral, Peaceful and Co-operative Cambodia.'

7 In-depth case studies based on interviews and documents that shed light on the decision-making process can provide important clues about the absence of Chinese personnel on these missions. Due to space limitations, this issue is beyond the scope of this article and hence such an effort was not undertaken.

8 For an interesting discussion on the subject, see International Crisis Group (2017). 


\section{References}

Aksu, E. 2018. The United Nations, Intra-state Peacekeeping and Normative Change. Manchester: Manchester University Press.

Allen, K. 2015. 'What China hopes to achieve with first peacekeeping mission..' $B B C$ [online]. 2 December. At https://www.bbc.com/news/world-africa-34976580 [Accessed on 4 May 2020].

Barber, L. 2014. Chinese Foreign Policy in the 'Going Out' Era: Confronting Challenges and 'Adaptive Learning' in the Case of China Sudan and South Sudan Relations. PhD thesis, London School of Economics and Political Science (LSE), UK.

Bariyo, N. 2014. 'China Deploys Troops in South Sudan to Defend Oil Fields, Workers.' Wall Street Journal [online]. 9 September. At https://www.wsj.com/articles/china-deploys-troops-in-south-sudan-to-defend-oil-fields-workers-1410275041 [Accessed on 4 May 2020].

Best, L. 2020. 'What Motivates Chinese Peacekeeping?.' Asia Unbound Blog [online], Council on Foreign Relations. 7 January. At www.cfr.org/blog/what-motivates-chinese-peacekeeping [Accessed on 2 May 2020].

Blanchard, B. 2017. 'China Formally Opens First Overseas Military Base in Djibouti.' Reuters [online]. 1 August. At https://www.reuters.com/article/us-china-djibouti/china-formally-opens-first-overseas-military-base-in-djibouti-idUSKBN1AH3E3 [Accessed on 4 May 2020].

Carvajal, D. 2010. 'Hunting for Liberia's Missing Millions.' The New York Times. 30 May. At https:// www.nytimes.com/2010/05/31/world/africa/31taylor.html [Accessed on 4 March 2021].

Chan, G. 2013. 'Power and Responsibility in China's International Relations.' In Y Zhang and G Austin (eds), Power and Responsibility in Chinese Foreign Policy. Canberra: Australian National University E Press, pp. 48-68.

China Daily [online]. 2014. 'China to send first infantry battalion for UN peacekeeping.' 22 December. At www.chinadaily.com.cn/china/2014-12/22/content_19142019.htm [Accessed on 4 May 2020].

Christensen, T. 2006. 'Windows of War: Trend Analysis and Beijing's Use of Force.' In A I Johnston and R S Ross (eds), New Directions in the Study of China's Foreign Policy. Stanford: Stanford University Press, pp. 50-85.

Embassy of the PRC in Liberia [online]. n.d. Bilateral Relations. At lr.chineseembassy.org/eng/sbgx/ t1836708.htm [Accessed on 12 March 2021].

Findlay, T. 1995. 'Cambodia: The Legacy and Lessons of UNTAC.' SIPRI Research Report No. 9. Oxford: Oxford University Press.

French, H. 2014. China's Second Continent: How a Million Migrants Are Building a New Empire in Africa. New York: Alfred A. Knopf.

Fung, C. J. 2016. 'What Explains China’s Deployment to UN Peacekeeping Operations?' International Relations of the Asia-Pacific 16 (3): 1-33.

Gill, B. and C.-H. Huang. 2009. 'China’s Expanding Role in Peacekeeping: Prospects and Policy Implications.' SIPRI Policy Paper. Stockholm: Stockholm International Peace Research Institute.

Harris, D. 1999. 'From 'Warlord' to 'Democratic' President: How Charles Taylor Won the 1997 Liberian Elections.' The Journal of Modern African Studies 37 (3): 431-455. 
He, Y. 2007. 'China’s Changing Policy on UN Peacekeeping Operations'. Asia Paper. July. Stockholm: Institute for Security and Development Policy.

Hirono, M. 2011. 'China's Charm Offensive and Peacekeeping: The Lessons of Cambodia - What Now for Sudan?'. International Peacekeeping 18 (3): 328-343.

International Crisis Group. 2017. 'China’s Foreign Policy Experiment in South Sudan.' Asia Report 288 [online]. 10 July. At https://www.crisisgroup.org/africa/horn-africa/south-sudan/288-china-s-foreign-policy-experiment-south-sudan [Accessed on 19 August 2020].

International Crisis Group. 2019. 'China’s Growing Role in UN Peacekeeping'. Asia Report 166 [online]. 17 April. At https://www.crisisgroup.org/asia/north-east-asia/china/china-s-growing-roleun-peacekeeping [Accessed on 19 August 2020].

Jakobson, L and D Zha. 2006. 'China and the Worldwide Search for Oil Security'. Asia Pacific Review 13 (2): 60-73.

Jiang, Z. 2000. Statement by President Jiang Zemin of the People's Republic of China at the Millenium Summit of the United Nations 6 September 2000. At https://www.fmprc.gov.cn/mfa_eng/ wjdt_665385/zyjh_665391/t24962.shtml [Accessed on 1 May 2020].

Kim, S S. 2006. 'Chinese Foreign Policy Faces Globalization Challenges.' In A I Johnston and R S Ross (eds), New Directions in the Study of China's Foreign Policy. Stanford: Stanford University Press, pp. 276-306.

Lanteigne, M. 2018 'The Role of U.N. Peacekeeping in China’s Expanding Strategic Interests.' United States Institute of Peace, Special Report 430 [online], 18 September. At https://www.usip.org/publications/2018/09/role-un-peacekeeping-chinas-expanding-strategic-interests [Accessed on 03 May 2020].

Lanteigne, M and M Hirono. 2012. China's Evolving Approach to Peacekeeping. London: Routledge. Lawson, B S. 2011. The Price of Peace: A Quantitative Analysis of Economic Interests and China's Involvement in United Nations Peacekeeping Operations. Master's Thesis, Georgetown University, USA. Lei, Z. 2011. 'Two Pillars of China’s Global Peace Engagement Strategy: UN Peacekeeping and International Peacebuilding.' International Peacekeeping 18 (3): 344-62.

Li, A. 2007. 'China and Africa: Policy and Challenges.' China Security 3 (3): 69-93.

Li, C-P. 2011. 'Norm Entrepreneur or Interest Maximiser? China’s Participation in UN Peacekeeping Operations, 2001-2010.' China: An International Journal 9 (2): 313-327.

Lin-Greenberg, E. 2009. Blue-Helmeted Dragons: Explaining China's Participation in United Nations Peace Operations. Master's Thesis, Massachusetts Institute of Technology, USA.

Liu, T. 2009. 'Marching for a More Open, Confident and Responsible Great Power: Explaining China's Involvement in UN Peacekeeping Operations.' Journal of International Peacekeeping 13 (1-2): $101-130$.

Medeiros, E S. 2009. China's International Behavior: Activism, Opportunism, and Diversification. Santa Monica: RAND.

Meng, W. 2019. 'Chinese peace: Untold stories on the ground in South Sudan.' China Daily [online]. 6 October. At global.chinadaily.com.cn/a/201910/06/WS5d99566da310cf3e3556ee1b.html [Accessed on 11 March 2021]. 
Ministry of Foreign Affairs [PRC]. 2002. China's Position Paper on Enhanced Cooperation in the Field of Non-Traditional Security Issues. Beijing. May 29th. At: https://www.fmprc.gov.cn/mfa_eng/ wjb_663304/zzjg_663340/gjs_665170/gjzzyhy_665174/2612_665212/2614_665216/t15318.shtml [Accessed on 25 January 2021].

Mulvenon, J. 2009. 'Chairman Hu and the PLA's 'New Historic Missions.' China Leadership Monitor 27 (Winter): 1-11.

Pang, Z. 2005. 'China's Changing Attitude to UN Peacekeeping.' International Peacekeeping 12 (1): 87-104.

Patey, L. 2014. The New Kings of Crude: China, India, and the Global Struggle for Oil in Sudan and South Sudan. London: C. Hurst \& Co.

Ponniah, K. 2018. 'In 1993, the UN tried to bring democracy to Cambodia. Is that dream dead?.' BBC News [online]. 28 July. At https://www.bbc.com/news/world-asia-44966916 [Accessed on 11 March 2021].

Shambaugh, D. 2013. China Goes Global: The Partial Power. Oxford: Oxford University Press.

Sharman, C. H. 2015. 'China Moves Out: Stepping Stones Toward a New Maritime Strategy' China Strategic Perspectives (9). Washington DC: National Defense University Press.

Sieckmann, I and O Triebel. 2018. A New Responsible Power China? China's Public Diplomacy for Global Public Goods. Stuttgart: Institut für Auslandsbeziehungen.

Stähle, S. 2008. 'China's Shifting Attitude towards United Nations Peacekeeping Operations.' The China Quarterly 195 (September): 631-55.

State Council [PRC]. 2020. China's Armed Forces: 30 Years of UN Peacekeeping Operations. Beijing. 18 September. At: http://english.www.gov.cn/archive/whitepaper/202009/18/content_WS5f6449a8c6d0f7257693c323.html [Accessed on 25 January 2021].

2011. China's Peaceful Development. Beijing. March 31th. At: http://english.www.gov.cn/ archive/white_paper/2014/09/09/content_281474986284646.htm [Accessed on 11 August 2020].

UN Digital Library [online]. 2014. Resolution 2155 (2014) / adopted by the Security Council at its 7182nd meeting, on 27 May 2014. At digitallibrary.un.org/record/771722 [Accessed on 12 March 2021].

UN Peacekeeping [online]. 2020. Troop and Police Contributors. At https://peacekeeping.un.org/ en/troop-and-police-contributors [Accessed on 15 April 2021].

UNAMIC [online]. n.d. Mandate. At https://peacekeeping.un.org/sites/default/files/past/unamicmandate.html [Accessed on 12 March 2021].

UNMIL [online]. n.d. Background. At unmil.unmissions.org/background [Accessed on 12 March 2021].

UNTAC [online]. n.d. Background. At peacekeeping.un.org/sites/default/files/past/untacbackgr2. html [Accessed on 12 March 2021].

USA for UNHCR [online]. n.d. South Sudan Refugee Crisis. At www.unrefugees.org/emergencies/ south-sudan [Accessed on 12 March 2021].

Wuthnow, J. 2020. 'The PLA Beyond Asia: China’s Growing Military Presence in the Red Sea Region. Institute for National Strategic Studies, National Defense University, Strategic Forum 303 (January): 1-16. 
Williams, P D and A J Bellamy. 2007. 'Contemporary Peace Operations: Four Challenges for the Brahimi Paradigm.' In H Langholtz, H Kondoch, and A Wells (eds), International Peacekeeping: The Yearbook of International Peace Operations. Leiden: Brill, pp. 1-28.

Xia, L. 2001. 'China: A Responsible Great Power' Journal of Contemporary China 10 (26): 17-25.

Yan, X. 2014. 'From Keeping a Low Profile to Striving for Achievement.' The Chinese Journal of International Politics 7 (2): 153-184.

Zhou, H. 2013. 'Dragon Under the Blue Helmet: A Quantitative Analysis of China's Motivation for Participation in UN Peacekeeping Operations.' African East-Asian Affairs 3: 31-61.

Zürcher, C. 2019. '30 Years of Chinese Peacekeeping.' Centre for International Policy Studies (CIPS) report [online]. University of Ottawa. At https://www.cips-cepi.ca/wp-content/uploads/2019/01/ 30YearsofChinesePeacekeeping-FINAL-Jan23-1.pdf [Accessed on 3May 2020].

\section{Acknowledgements}

This research was funded by the National Postdoctoral Program (PNPD), offered by the Coordination for the Improvement of Higher Education Personnel (CAPES), a foundation within the Brazilian Ministry of Education.

\section{About the author}

Renan Holanda Montenegro is a Postdoctoral Researcher (PNPD-Capes) at the Political Science Graduate Program at the Federal University of Pernambuco (UFPE). He is also an Associate Researcher at the Asian Studies Coordination, linked to the UFPE's Centre for Advanced Studies (CEA). He received his $\mathrm{PhD}$ in Political Science from UFPE and spent a mobility period under the Erasmus Fellow-Mundus Program at the New University of Lisbon. He holds a Master's degree in International Relations from the State University of Rio de Janeiro (UERJ). In the period between 2017 and 2021, he was a Lecturer at the Departments of International Relations at the Federal Universities of Sergipe (UFS) and Paraíba (UFPB). His current research interests cover issues related to Chinese Foreign Policy, especially Sino-Brazilian and Sino-African relations. 


\section{A China nas Operações de Paz da ONU: Uma Avaliação de 30 anos (1990-2019)}

Resumo: O presente artigo apresenta uma ampla avaliação sobre o destacamento de pessoal chinês para operações de paz ao longo das últimas três décadas (1990-2019). Para tanto, um conjunto de dados original foi construído a partir de dados coletados do Departamento de Operações de Paz da ONU (DPO). Os seguintes quatro indicadores foram analisados: (i) contribuição total de pessoal por ano; (ii) contribuição de pessoal por missão; (iii) contribuição de pessoal em relação ao contingente total da missão; e (iv) contribuição de pessoal em uma determinada missão em relação ao total destacado pela China naquele ano. De modo geral, as missões da ONU na Libéria (UNMIL) e no Sudão do Sul (UNMISS) foram os principais destinos das forças chinesas de manutenção de paz no século XXI, enquanto o Camboja (UNTAC) foi, de longe, o único lugar onde a China se envolveu profundamente durante a década de 1990. Além de exibir dados descritivos, o artigo também analisa brevemente o envolvimento chinês nessas operações.

Palavras-chave: China; operações de paz; UNMIL; UNMISS; UNTAC.

Received on 07 May 2020 and approved for publication on 01 April 2021. https://creativecommons.org/licenses/by-nc/4.0/ 